ISSN 2410-1176 (Print) Вісник КНУКіМ. Серія Мистецтвознавство. Вип. 39. ISSN 2616-4183 (Online)

УДК 7.091.01

Мельник Мирослава Миколаӥвна, кандидат мистеитвознавства, доиент, Київський національний університет культури і мистеитв, вул. С. Коновальия,36, Київ, Україна, 01133, https://orcid.org/0000-0002-2553-5509 mirchukmmm@gmail.com

\title{
ІМПРОВІЗАЦІЯ ЯК ОДИН ІЗ НАЙВАЖЛИВІШИХ АСПЕКТІВ ПРОФЕСІЙНОӤ МАЙСТЕРНОСТІ АРТИСТА ЕСТРАДИ
}

Мета - з'ясувати специфічні особливості імпровізації в майстерності артистів естради на відміну від акторів театру. Методологія дослідження. У дослідженні застосовано методи теоретичного, емпіричного та компаративного аналізу. Завдяки детальному аналізу, визначена роль імпровізації як майстерного прийому в роботі артиста; висвітлено принципи формування практичних сценічних навичок імпровізації в артистів естради. Наукова новизна полягає у виявленні характерних особливостей застосування імпровізації в сценічній діяльності артиста естради та принципах оволодіння майстерністю імпровізувати в умовах сценічної гри. Висновки. Майстерність артиста імпровізувати в умовах сценічної гри визначає його професійний рівень. У такому випадку випливають два аспекти: або артист талановитий від природи, або це практичний досвід, набутий роками. Формування сценічних навичок імпровізації відбувається завдяки основним складовим: пам'ять, творча асоціативна уява, дієве слово та пластична виразність. На відміну від актора театру, артист естради напряму спілкується з глядачем засобами сценічної виразності. Визначення ефективних прийомів застосування імпровізації, висвітлених у даних матеріалах, дадуть можливість сучасним артистам естради вдосконалювати свій професійний досвід та акторську майстерність у сучасному сценічному просторі. перформанс.

Ключові слова: артист естради; імпровізація; конферанс; гумористична імпровізація;

Мельник Мирослава Николаевна, кандидат искусствоведения, доиент, Киевский национальный университет культуры и искусств, ул. Е. Коновальца,36, Киев, Украина

Импровизация как один из важных аспектов профессионального мастерства артиста эстрады

Цель - определить специфические особенности искусства импровизации в мастерстве артистов эстрады современного сценического искусства. Методология исследования. В исследовании применены методы теоретического, эмпирического и компаративного анализа. Благодаря детальному анализу, определена роль импровизации как искусного приема в работе артиста; освещены принципы формирования практических сценических навыков импровизации в артистов эстрады. Научная новизна заключается в раскрытии характерных особенностей применения импровизации в сценической деятельности артиста эстрады и принципах овладения мастерством импровизировать в условиях сценической игры. Выводы. Мастерство артиста импровизировать в условиях сценической игры определяет его профессиональный уровень. В таком случае выплывают два аспекта: либо артист талантливый от природы, либо это практический опыт, приобретенный годами в достижении техники импровизировать. Формирование сценических навыков импровизации происходит благодаря основным составляющим: память, творческая ассоциативное воображение и действенное слово. В отличии от артиста театра, артист эстрады напрямую общается со зрителем средствами прямой контактной коммуникации, устанавливает вербальным способом тесную взаимосвязь с публикой. Определение эффективных приемов применения импровизации, освещенных в данных материалах, дадут возможность современным 
артистам эстрады усовершенствовать свой профессиональный опыт и актерское мастерство в современном сценическом пространстве.

Ключевые слова: артист эстрады; импровизация; конферанс; юмористическая импровизация; перформанс.

Melnyk Myroslava, PhD in Art Criticism, Associate Professor, Kyiv National University of Culture and Arts; 36, Y. Konovaltsia St., Kyiv, Ukraine

Improvisation as one of the most important aspects of the variety artist professional skills

The purpose of the article is to find out the specific features of the variety artists improvisation, been quite different from the theatre actors. Methodology of the research. The study addresses to such methods of analysis as theoretical, empirical, and comparative ones. On the basis of the detailed analysis, the author determines the role of improvisation as a skilful reception in the artist's work; highlights the principles of the practical scenic skills of improvisation formation of the variety artists. The scientific novelty consists in revealing the characteristic features of the improvisation use in the stage performance of the variety artist and the principles of skills mastering to improvise in the conditions of the stage game. Conclusions. The artist's ability to improvise in a stage game determines his professional level. In this case, there are two aspects: either the artist is talented by nature, or it is a practical experience gained over the years. The formation of stage skills of improvisation is due to the main component: memory, creative associative imagination, effective word and plastic expression. In contrast to the actor of the theatre, the variety artist directly communicates with the viewer with the means of stage expressiveness. Identifying effective techniques for applying improvisations, highlighted in these materials, will enable contemporary variety artists to improve their professional experience and acting skills in contemporary stage space.

performance.

Key words: variety artist; improvisation; conferance; humorous improvisation;

Вступ. Сучасна естрада XXI ст. - складний культуротворчий механізм, основу якого складають різноманітні форми та жанри сценічного мистецтва. Підвищений інтерес суспільства до естрадних та театральних дійств диктується потребами часу. Попри динамічний розвиток сценічних мистецтв, широке застосування сучасних мультимедійних технологій, використання інноваційних засобів виразності, головним $\epsilon$ i залишається артист - професіонал, майстер своєї справи, який вправно імпровізує в запропонованих обставинах.

Постановка проблеми. Сьогодні в незалежній Україні постійно відбувається процес оновлення естрадних форм, який пов'язаний з впливом зовнішніх та внутрішніх факторів у мистецтві в цілому. Сучасний глядач стає більш вимогливим до майстерності артистів, а саме: вміння імпровізувати в умовах сценічної гри. Тому, в науковому й практичному сенсі постає проблема у систематизації певних закономірностей, які полягають у вмінні артистів імпровізувати, що дає можливість глядачам відчувати себе співучасниками естрадного дійства. Для дослідників становить науковий інтерес спроба аналізу імпровізації на сучасній естраді, визначення основних складових імпровізації, які формують майстерність артистів. Саме в мистецтві естради, на відміну від мистецтва театру, недостатньо досліджено питання застосування імпровізації в професійній діяльності артиста. Необхідність розкриття саме цього аспекту імпровізації на естраді продиктована відсутністю науково-практичних рекомендацій щодо застосування імпровізації саме в умовах вітчизняної сучасної естради.

Актуальність. Естрадний простір сьогодні залежить від конкретної соціальноекономічної формації, від культурних традицій та суспільної свідомості. Мистецтво естради в процесі розвитку суспільства набуває сучасних видовищних форм. Це особливий простір, який має величезну силу емоційного впливу на артиста та глядача. Естрада - мистецтво індивідуальне. Це видовищне, вражаюче поєднання майстерності та стилю, де центральною фігурою є артист. 
Можна стверджувати, що імпровізація виникла ще з часів, коли зародилося мистецтво театру. Однак, дослідження в цьому напрямку завжди буде актуальним, оскільки в зв'язку з постійними змінами в культуротворчих процесах, мистецтво на естраді буде вдосконалюватись та модернізуватись відповідно до вимог сучасності.

Артист може виступати в одному жанрі: хореографічний, вокальний, музичний, розмовний, але наскільки різноманітні можуть бути їх методи, стилі та, звичайно, репертуар, який $є$ основою кожного номера, настільки й буде залежати рівень професіоналізму виконавця. Тому актуальним сьогодні буде розглянути мистецтво імпровізації, яке найбільше визначає рівень сценічної майстерності артиста.

Аналіз досліджень. Дослідники, науковці, теоретики та практики наголошують, що головним у професії артистів всіх жанрів $\epsilon-$ майстерність імпровізації. Так, С. Уварова (2011), досліджуючи творчість Аркадія Райкіна, у своїх працях зазначала, для нього важливим був талановитий, обдарований артист. Порівняльний аналіз специфіки професійної діяльності артиста естради та актора театру проводив В. Кісін (1999). Вимоги до майстерності, якими повинен володіти артист естради, розробив у своїх підручниках С. Клітін (1987).

М. Чехов (1995), окрім таланту та професійної майстерності артиста, наголошував саме на його вмінні імпровізувати, адже саме імпровізація $\epsilon$ основою професії. Єжи Гротовський (2003) визначив види імпровізації: хаотична та гармонічна. Звєрєва Н. та Лівнев Д. (2008) акцентували увагу на творчій уяві, яка тісно пов'язана з мистецтвом імпровізації, як одна 3 найважливіших меж вищого акторського таланту. Фішер В. (2016) досліджував та аналізував мистецтво стендапу. У своїх працях він наголошує, що головне у цій естрадній формі для артиста мати неабиякий талант гумориста, відчувати аудиторію та володіти майстерністю імпровізації. Станіславська К. (2016) у своїй монографії розкривала феномен перформансу. Вона зазначала, що дану форму проводять у теперішньому часі, тут i зараз. А це значить, що основою перформансу є імпровізація.

Толшин А. (2014) на основі практичного досвіду в своїх працях розглядав імпровізацію як феномен в акторській майстерності. Крипчук М. та Колтак К. (2018) досліджували відмінність у природі імпровізації між артистом естради та актором театру. Однак, можна стверджувати, що все ж імпровізація в майстерності артиста естради потребує детальнішого аналізу характерних іiі особливостей та принципах оволодіння імпровізацією в умовах сценічної гри.

Мета статті - визначити основні складові професійної майстерності артиста естради, розкрити особливості імпровізації, яка визначає рівень майстерності артиста естради, визначити роль імпровізації на естраді та з'ясувати специфічні особливості імпровізації в майстерності артистів естради на відміну від акторів театру.

Виклад основного матеріалу. Сьогодні сценічні жанри на естраді широко популяризуються, відбувається процес оновлення традиційних форм, в яких основою $\epsilon$ естрадний номер. Проте, аналізуючи сучасне мистецтво естради, чітко можна зрозуміти, що майстерність виконання естрадного номера майже повністю залежить від самого виконавця, адже увага глядача зосереджена на артисті. С. Клітин (1987) створює цілий комплекс вимог, якими повинен володіти артист естради. «Синтетичні навички, якими повинен володіти кожен естрадний виконавець, мова про те, що естрада дуже поважає артиста, який одночасно володіє декількома професійними якостями; дії естрадного виконавця, на відміну від театрального актора, повинні бути дуже стислими та лаконічними; особистісні якості повинні займати не останнє місце у майстерності артиста. У даному випадку культура й освіченість артиста естради стають не просто значним фактором. Виконавець на естраді завжди залишається із глядачем віч-на-віч та дуже швидко “вгадується" рівень освіченості та внутрішньої наповненості. Роль артиста в житті не менше складна, ніж в умовах сцени та естради. Артист на противагу іншим людям “нормальної” професії, знаходиться в колі великої колективної уваги. I саме така публічність вимагає від артиста постійно пам'ятати про те, що його діяльність у побутовому житті стає певним еталоном для моральної та естетичної поведінки на сцені» (Клітин, 1987, с. 93). 
Майстерність артиста естради полягає здебільшого в його можливості тримати увагу глядача, поєднувати в собі вміння володіти декількома жанрами мистецтва естради, синтезувати їх у своєму виконанні та таким чином створювати повноцінний естрадний номер. Розглядаючи сценічну майстерність артиста естради, окрім таланту та професійної майстерності, варто акцентувати увагу на майстерності артиста імпровізувати, адже така сценічна гра займає надзвичайно важливе місце в професії. М. Чехов (1995) головним у майстерності актора виділяв його творчу індивідуальність, яка дає можливість артисту самостійно творити в запропонованих обставинах, тобто імпровізувати. «Усе, що в грі актора приймає застиглу, нерухому форму, відводить його від самої суті його професії імпровізації» (Чехов, 1995, с. 235).

Великий артист Аркадій Райкін приділяв увагу природній обдарованості, таланту. Артистам-початківцям він завжди радив, насамперед, засвоїти найменші деталі та нюанси професії, оволодіти всіма законами акторської майстерності, що є основою для всіх творчих особистостей, які пов'язують свою діяльність зі сценою. Крім того, артист естради повинен мати додаткові якості, обумовлені специфікою естрадної форми. Передусім, він виходить сам на сам до глядача. А це підвищує його відповідальність за кожен жест, рух, за кожне слово, яке він доносить до публіки. А. Райкін акцентував увагу на тому, що артист повинен бути ініціативним, всесторонньо обізнаним та враховувати інтереси публіки.

Специфіка естрадного номера полягає в його короткометражності, стислості, що значно обмежує в часі виступи артистів. За короткий час артист повинен налагодити взаємозв’язок з публікою, тонко відчути ії настрій. Досліджуючи творчість великого артиста естради Аркадія Райкіна, С. Уварова (2011) зазначала, що для нього дуже важливим було, коли актор відчуває глядача як партнера.

Безперечно, на естраді й у драматичному театрі повинен бути саме талановитий артист, чого на жаль, сьогодні не достатньо в сучасному сценічному мистецтві. Проте, «якщо порівнювати мистецтво театру й естради, то можна знайти відмінність у природі імпровізації, неоднаковість першопричин. У драматичному театрі, зазвичай, це імпровізація всередині сценічної дії. На естраді до цього додається імпровізація в спілкуванні з залом для глядачів. До того ж, кожен жанр надає різну ступінь можливості артисту естради імпровізувати. Наприклад, якщо естрадний виконавець почне імпровізувати під час виконання складного трюку, то це може привести або до зриву трюку або до травми актора» (Крипчук та Колтак 2018, с. 44).

Кожен артист естради будує свої виступи за принципом «для глядача - 3 глядачем». Він не відгороджений від глядача ні завісою, ні рампою, діючи, зазвичай, серед глядачів, носій естрадної інформації мимоволі повинен застосовувати прийоми створення власного образу, відповідні фізичним умовам його існування. Це й призвело до того, що побудова образу на естраді відбувається в безпосередньому спілкуванні актора з глядачем. Артист естради ніби підкреслює нерозривність ідейного зв'язку з тим глядачем, для якого він творить. А це досягається за допомогою вміння професійно імпровізувати в умовах сценічної гри.

Імпровізація займає вагоме місце в кожному з жанрів естради: у музичному - це джаз, що народився 3 колективних імпровізацій, у хореографічному - контемпорарі денс (народжений у тілі, що звільнене від умовностей) та контактна імпровізація, в оригінальному - пантоміма та клоунада, у розмовному - конферанс та гумористична імпровізація.

Імпровізація - найвищий рівень майстерності артиста, той етап його творчого розвитку, коли він може, вільно володіючи жанром, відходити від заздалегідь підготовлених й відрепетируваних елементів образу, таким чином створюючи нове забарвлення свого персонажу.

Імпровізацію не дарма вважають найважливішою ознакою мистецтва естради. Поперше, не можна плутати імпровізацію $з$ приблизністю, зі словесною й пластичною розбещеністю. По-друге, імпровізація - не просто випадкова сценічна дія. Імпровізація як один зі складних прийомів створення естрадного номера, може застосовуватися також як 
тренінг для розвитку уяви та фантазії самого артиста. Пошук нових, нестандартних рішень образу робить імпровізацію яскравою, цікавою та насиченою. Її професійне використання призводить до створення повноцінних творів мистецтва естради, за умови досконалого володіння артистом специфікою дієвого слова, сценічної пластики та творчої асоціативної уяви.

«Розвиток уяви тісно пов’язаний з вихованням імпровізації як однієї з найважливіших необхідних меж акторського обдарування. Оригінальна імпровізаційність, тобто гострота, сприйняття свободи уяви, легка емоційна збудженість, багатство образних асоціацій, - це вже свідоцтво високого професіоналізму, шлях до якого довгий та не легкий» (Зверева та Ливнев, 2008, с. 91).

Розглядаючи імпровізацію артистів у створенні естрадних номерів, варто зауважити, що на «мікрорівні» - на рівні створення основи, найменшого елемента сценічного мистецтва на естраді - номеру - імпровізація стає одним із визначальних факторів і допоміжним засобом для його створення. «...Можна стикнутися з відмінністю між імпровізацією, яка проявляється хаотично, й імпровізацією, яка виступає як повторне пристосування (реадаптація) до тої чи іншої структури, тобто гармонічною імпровізацією» (Гротовский, 2003, c. 231).

Сьогодні на естраді є безліч артистів, які працюють у різноманітних жанрах мистецтва естради, проте кожен артист повинен шукати свій індивідуальний образ, стиль та манеру імпровізувати.

Безперечно, найпопулярнішим серед глядацької аудиторії та артистів є розмовний естрадний жанр - синтез словесного (літературного) матеріалу з акторською майстерністю. Слово є найпотужнішим та дієвим ідейно-емоційним засобом виразності. Зацікавленість глядачів до даного жанру викликана, насамперед гостротою, актуальною проблематикою, яка розкривається у текстах, висвітленням певної тематики, що хвилює кожного глядача.

Перш, ніж створити естрадний номер розмовного жанру, потрібно досконало засвоїти його специфіку та особливості, визначити характерні елементи та поступове оволодіння професійними навичками дієвого слова, чітко здійснювати логічний та дієвий аналіз тексту. Тому основним при роботі над номерами розмовних жанрів $\epsilon$ вербальна установка взаємозв'язку артиста 3 глядацькою залою за допомогою імпровізації. Змусити артиста імпровізувати не можливо. Вдало імпровізувати можна тільки тоді, коли є творче натхнення, створена легка й невимушена атмосфера та встановлений тісний взаємозв'язок артиста 3 публікою.

Для артиста розмовного жанру слово є головним засобом донесення ідеї та змісту матеріалу, проте обов'язковою вимогою є засвоєння специфіки та методики роботи над номером, відпрацювання всіх характерних деталей образу, манери виконавства, комплекс комічних, гумористичних реплік, жартів, реприз або цікавих, несподіваних трюків. Головною складовою розмовних жанрів є наявність всіх драматургічних особливостей твору в стислому, так би мовити, спресованому, вигляді.

Однак, найбільшої популярності на сучасній естраді набув особливий естрадний розмовний жанр - конферанс. У підготовці конферансу суттєвим завжди є вдале рішення художнього сценічного образу. Особливу увагу при створенні сценічного образу потрібно приділяти індивідуальним якостям виконавця.

При тому, що конферансьє прагнуть імітувати імпровізаційну манеру, склалася певна форма конферансу: вступ до концерту, «підводки» до номерів, репризи, жарти, власний номер й прощальні слова. Так, розкішна невимушена манера конферувати притаманна тільки Штепселю і Тарапуньці (Є. Березін та Ю. Тимошенко). Сьогодні жоден артист не може замінити на естраді цих великих майстрів слова.

Дехто вважає, що сьогодні жанр конферансу відмирає. Та це не так. Він начебто переродився, трансформувався у відповідності до вимог і потреб сучасності, однак його представників залишилося дуже мало. Зі сміливістю можна констатувати, що нині конферанс присутній на естраді лише в елементах. Розглядаючи творчість сучасних артистів української 
естради вокального жанру, можна зазначити, що кожен 3 них $є$ не тільки виконавцем популярних пісень, а й, в певній мірі, виступає в ролі конферансьє свого сольного концерту. Так, відома артистка естради Оля Полякова при проведенні власних концертів, вільно спілкується з глядачем, застосовуючи вдалі жарти, гумор, репризи.

Не менш популярна на естраді серед імпровізаційних форм розмовного жанру сьогодні є гумористична імпровізація, суть якої полягає у розмовному клубному стилі та включає виступи артистів перед глядацькою залою 3 монологами або мініатюрами. Синонімом гумористичної імпровізації можна назвати стендап. Гумор, зазвичай, оригінальний - з самого початку артист $є$ й автором, й постановником свого шоу, а багато номерів будуються на імпровізації. «Створюючи монолог, артист створює один образ, один персонаж і від його імені спілкується з глядачами або розповідає кумедні історії від свого імені. Такі стендапи мають на меті не висміяти когось, а просто посміятися над ситуацією. Для того, щоб створити вдалий стендап - потрібно володіти високою майстерністю артиста та мати добре почуття гумору. Адже, іноді артист повинен імпровізувати на сцені, а щоб імпровізація викликала сміх, потрібно мати неабиякий талант гумориста» (Фішер, 2016, с. 185).

27 листопада на телеканалі «Україна» відбулася прем’єра шоу Олександра Скічка «Без паніки». Суть шоу полягає в обговоренні актуальної проблеми через призму гумору. Маючи за основу сценарій, учасники користуються ним в основному як сценарним планом, не оминаючи можливості зайвий раз використати імпровізацію для встановлення тіснішого контакту з глядачем, яскравіше підкреслити ту чи іншу новину, урізноманітнити програму й наситити їі яскравими жартами.

Сьогодні, аналізуючи імпровізацію як самостійну форму існування, можна констатувати що вона $є$ й основою, й розвитком, і кульмінацією естрадного видовища. Імпровізація займає провідне місце майже в усіх жанрах сценічних мистецтв. Проте, найістотнішим є створення театрів імпровізації. Варто зазначити, що ще в комедії дель арте імпровізація використовувалася як основний метод створення вистав. Однак, там існували окремі, історично сформовані образи-маски, за допомогою яких розвивалися події, налаштовували акторів на характерність їхніх образів. Сьогодні ж ми говоримо про імпровізацію як про самостійний метод у майстерності артиста естради.

Досить популярним сучасним театром імпровізації в Києві $є$ театр «Чорний квадрат». Імпровізація для цього театру - це спосіб театральної гри, коли подання народжується «тут і зараз», стаючи автентичним і неповторним. Актори й глядачі стають співучасниками дійства, яке, зазвичай, $є$ несподіваним і для глядачів, і для самих акторів.

Варто акцентувати увагу на одній із форм акціонізму - перформанс, в основі якого полягає імпровізація. Перформанс належить до двох мистецьких напрямів. Перший - до образотворчого мистецтва, де квазітеатральне дійство виконує професійний художник поодинці або з декількома найнятими статистами, колегами-соратниками, зазвичай без словесного супроводу. Другий - до театралізовано-пластичних дійств. К. Станіславська (2016, с. 90) зазначає, що «...перформанс сьогодні - це, напевне, найщиріша з мистецьких форм, тому що відбувається тут і зараз, презентуючи особистість митця в теперішньому просторі й теперішньому часі, в цю саму мить. Це головна 3 відмінностей театру i перформансу: глядач і художник знаходяться у реальному, а не ілюзорному світі. Більше того, сучасний театр та нові форми театральності набувають сьогодні перформативних ознак, що дає право прогнозувати як раз таки не театралізацію перформансу, а перфоматизацію театру».

Перформери, які $є$ організаторами й учасниками перформансу, за допомогою імпровізації поєднують звичні явища, буденні ситуації, після чого вони набувають зовсім іншого ідейного змісту. Це сценічна гра, яка не потребує спеціальної підготовки та репетицій, тут відсутній чіткий драматургічний текст, вся сценічна ситуація розігрується відразу на очах у глядача в прямому процесі виконання. Важливою особливістю імпровізації $\epsilon$ збіг у часі моментального втілення творчого задуму перформанса та сам момент його створення. Саме завдяки вдалій імпровізації перформери мають можливість адаптувати тему перформанса до нових обставин, до нового глядача, до іншого місця проведення. Велике 
значення при імпровізації в перформерів відіграють такі складові як увага, винахідливість, пам'ять, емоційний заряд, бездоганний гумор, миттєва реакція на непередбачувані ситуації в глядацькій залі, координація та багата уява. Тому важливим у перформансі $є$ імпровізаційноасоціативна дія в запропонованих обставинах. Завдяки цим складовим елементам перформери досягають успіху, а сам перформанс має соціальну значимість у суспільстві.

Свобода поведінки - це одна 3 найбільших цінностей як при роботі артиста естради над індивідуальним номером розмовного жанру, так й у театрах імпровізації. Творча особистість - це людина, яка творить тому, що вона вільна. А обмеження, які накладаються на цю свободу, бар'єри вона сприймає як джерело, від якого можна відштовхуватися. А. Толшин $(2014$, с. 14) трактував мистецтво імпровізації як феномен, який «...3'являється у виконавській творчості там, де публіка сприймає не тільки результат, а й сам процес творчості, а художник є одночасно й автором, й виконавцем. У синтетичному театральному мистецтві різноманіття видів сценічної імпровізації зумовлено формою $\mathrm{i}$ жанром театрального дійства».

Наукова новизна полягає у виявленні характерних особливостей застосування імпровізації в сценічній діяльності артиста естради та принципах оволодіння майстерністю імпровізувати в умовах сценічної гри. Встановлено, що вміння артистів імпровізувати в сценічному просторі дає можливість для створення якісно нових номерів за умови, якщо імпровізація спрямована на досягнення поставленого надзавдання, яке визначається конкретними ігровими умовами.

Висновки. Отже, майстерність артиста імпровізувати на сцені проявляється через професійну творчу діяльність. Професійна діяльність має основні складові: ідейне спрямування, індивідуально-творчий характер артиста як особистості, оптимальність вибору новітніх засобів ідейно-емоційного впливу та високу майстерність імпровізувати. Отже, майстер своєї справи, фахівець мистецької галузі чітко уявляє мету своєї професії й, відповідно, творчо добирає засоби її вирішення.

На сучасній естраді досягнення митців минулих століть переосмислюються, трансформуються, впроваджуються в життя у новому сценічному трактуванні, 3 урахуванням смаків та попиту сучасного глядача. Те, що в XX ст. здавалося б неможливим, сьогодні відновлюється на новому етапі у складній єдності, у своєрідному художньому синтезі. Проте, уся розроблена теорія майстерності артиста належить діячам мистецтв радянських часів й відображає ідеологію того часу, а тому не може бути актуальною на сучасному етапі розвитку вітчизняного мистецтва естради. Ця теорія не може слугувати завершеною основою для професійних артистів естради, тому потребує оновлень й ретельної переробки відповідно до умов сучасності. На подальше дослідження науковців заслуговує наступне питання: створення практичної методики, яка буде спрямована на розвиток творчих здібностей артистів естради імпровізувати в умовах сучасної сценічної гри.

\section{Список використаних джерел}

1. Гротовский Е. От Бедного театра к Искусству-проводнику / перев. с польск., составл. вступит. ст. и примеч. Н. З. Башинджагян. Москва: Артист. Режиссер. Театр, 2003. 351 с.

2. Кісін В. Б. Режисура як мистецтво та професія. Життя. Актор. Образ: Із творчої спадщини. Київ: Видав. дім «КМ Academia», 1999. 268 с.

3. Клитин С. С. Эстрада: Проблемы теории, истории и методики. Ленинград: Искусство, 1987. 190 с.

4. Крипчук М. В., Колтак К. І. Проблеми розвитку та удосконалення психотехніки артиста естради. Культорологічний альманах. Вінниця, 2018. Вип. 10. С. 43-45.

5. Создание актерского образа: теоретические основы / Сост. и отв. ред. Н. А. Зверева и Д. Г. Ливнев. Москва: Изд-во «ГИТИС», 2008. 224 с.

6. Станіславська К. І. Мистеџько-видовищні форми сучасної культури : монографія. Вид. 2-ге, перероб. і доп. Київ: НАККіМ, 2016. 353 с. : іл. 
7. Толшин А. В. Импровизация в обучении актера. Санкт-Петербург: Государственная академия театрального искусства, 2014. 160 с.

8. Уварова Е. Д. Аркадий Райкин. Москва: Молодая гвардия, 2011. 383 с.

9. Фішер В. М. Культуротворчі аспекти стендапу як новітнього жанру естради. Украйна і світ у третьому тисячолітті: політичний, економічний, правовий та культурний виміри: матеріали II Всеукр. наук.-практ. конф., Одеса, 9 грудня, 2016 р. Одеса: Держ. заклад «Південноукр. нац. пед. ун-т імені К. Д. Ушинського», 2016. С. 184-186.

10. Чехов М. Литературное наследие. В 2-х т. Т. 2. Об искусстве актера. Москва: Искусство, 1995 с. 588

\section{References}

1. Chekhov, M. (1995). Literaturnoe nasledie [Literary heritage.] Moskva: Iskusstvo.

2. Fisher, V.M. (2016). Kulturotvorchi aspekty stendapu yak novitnoho zhanru estrady [Kulturotvorchesky aspects of stand-up as new genre of stage]. Ukraina $i$ svit $u$ tretomu tysiacholitti: politychnyi, ekonomichnyi, pravovyi ta kulturnyi vymiry: Materialy II Vseukrainskoi naukovo-praktychnoi konferentsii. Ukraine, Odesa, December 9 2016. Odessa: State institution "South-Ukrainian National Pedagogical University named after KD Ushinsky", pp. 184-186.

3. Grotovskii, E. (2003) Ot Bednogo teatra k Iskusstvu-provodniku [From Poor Theater to Art Guide]. Translated from Polska by N. Z. Bashindzhagyan. Moskva: Artist. Rezhisser. Teatr.

4. Kisin, V.B. (1999). Rezhysura yak mystetstvo ta profesiia Zhyttia. Aktor. Obraz: Iz tvorchoi spadshchyny [Direction as art and profession of Life. Actor. Character: Froma creative inheritance]. Kyiv: Vydavnychyi dim «KM Academia».

5. Klitin, S.S. (1987). Estrada: Problemy teorii, istorii i metodiki: Uchebnoe posobie [Stage: Problems of theory, history andmethodology]. Leningrad: Iskusstvo.

6. Krypchuk, M.V., Koltak, K.I. (2018). Problemy rozvytku ta udoskonalennia psykhotekhniky artysta estrady [Problems of development and improvement of psycho-technique of the stage artist], Kultorolohichnyi almanakh, issue 10, pp. $43-45$.

7. Stanislavska, K.I. (2016). Mystetsko-vydovyshchni formy suchasnoi kultury [The artistic and spectacular forms of modern culture]. Kyiv: National Academy of Cultural and Arts Management.

8. Tolshin, A.V. (2014). Improvizatsiya v obuchenii aktera [Improvisation in training of the actor]. Sankt-Peterburg: Gosudarstvennaya akademiya teatral'nogo iskusstva.

9. Uvarova, E.D. (2011). Arkadii Raikin [Arkady Raikin]. Moskva: Molodaya gvardiya.

10. Zvereva, N.A., Livnev, D.G. eds. (2008). Sozdanie akterskogo obraza: teoreticheskie osnovy [Creating an actor's image: theoretical foundations]. Moskva: Izd-vo «GITIS».

(C) Мельник M. М., 2018

Стаття надійшла до редакиії: 11.07.2018 